\title{
Learning and Teaching as Communicative Actions: A Mixed-Methods Twitter Study
}

\author{
Jenny S. Wakefield* \\ Department of Learning Technologies \\ College of Information \\ University of North Texas, USA \\ E-mail: JennyWakefield@my.unt.edu
}

\author{
Scott J. Warren \\ Department of Learning Technologies \\ College of Information \\ University of North Texas, USA \\ E-mail: Scott.Warren@unt.edu
}

\section{Metta Alsobrook}

Institutional Research and Effectiveness

Averett University, USA

E-mail: Metta.Alsobrook@Averett.edu

*Corresponding author

\begin{abstract}
Our paper examines the design of a course that utilized the real-time information network Twitter to spark reflective thinking and communication based on classroom topics. A major goal was to increase discourse amongst students and enhance learning through encouraging student time on task. The innovation followed guidelines set forth in the Learning and Teaching as Communicative Actions theory to augment student learning experience via more active communication and increased content sharing among students, towards a goal of building a social learning community. In this mixed methods study, we found diverse student perceptions of the use of Twitter; both very positive views of the tool as a means of supporting discourse and those views of the tool having little benefit to student's own learning. The female students in this study, perceived the tool to significantly more support the social learning community in the interactive environment than did male students.
\end{abstract}

Keywords: Twitter; LTCA Theory; Social Presence; Social Networking; Communication; Communities of Practice $(\mathrm{CoP})$

Biographical notes: Jenny S. Wakefield works as a Web Developer and Instructional Designer at the University of Texas at Dallas and is a $\mathrm{PhD}$ learner and Research Assistant at the University of North Texas in the College of Information. In her research she focuses on instructional design, social networks learning, and virtual worlds. She has been on the editorial board for several books.

Scott J. Warren works as an Associate Professor of Learning Technologies at 
the University of North Texas. His research examines the use of emerging online technologies such as immersive digital learning environments and educational games and simulations in K-20 settings. Prior to working in higher education, he taught both social studies and English in public schools. His early work included creating the Anytown world to support writing, reading, and problem solving. His current work includes The 2015 Project and Refuge alternate reality courses.

Metta Alsobrook works as a Director of Institutional Research and Effectiveness at Averett University in Virginia. She is responsible for planning, developing, directing, evaluating, conducting institutional compliance and research. Prior to working at Averett she worked at the University of Texas at Dallas and served as assessment coordinator. She has taught face-to-face and online classes. Her recent research examines assessment of student learning outcomes in higher education. Her current research focuses on student retention and persistence in college.

\section{Introduction}

Imagine life without the technologies many rely on every day: the computer, smart phone, tablet PC, even our automobiles are computers on wheels. In many western cultures, we have grown so accustomed to the use of these tools for communication, discourse, and social activities that it is hard to envision us without them. By collaborating in social networks, computer users around the globe now contribute to a new way of learning. This learning allows reshaping of knowledge, information, and culture, and informs how we create and share content "between individuals, groups, and societies" (Somerville \& Brar, 2010). Learning together using computer mediated communication (CMC) in this connected world allows both students and facilitators of learning to step outside of the brick-and-mortar walls of schools and learn in the real world.

Lave and Wenger (1991) first coined the term communities of practice (CoP), defining it as "people who engage in a process of collective learning in a shared domain of human endeavor" (Wenger, 2006). Wenger further clarified the concept, emphasizing that a $\mathrm{CoP}$ is a dynamic community where learning involves everyone. He added that, in education, "a class is not a primary learning event. It is life itself that is the main learning event" and he therefore argues schools have an obligation to transfer into the real world learning, because "learning happens in the world." In educational settings, learning with computers influences instructor communication strategies in the classroom, requiring many to rethink the way they teach (Neo \& Neo, 2004). One key challenge in the development of online educational activities is encouraging meaningful communication that enhances the learning experience while concurrently helping learners synthesize and thereby more deeply understand course content and also connect learning to the real world. CMC offer instructors a means to monitor and participate in student meaningmaking processes, especially in online learning environments and as instructors learn from such communication, they become more prepared for future instructional design (Paulus, Payne, \& Jahns, 2009). Wakefield and Warren (2012) found that, when examined through a pragmatic lens, leveraging tools such as blogs and microblogs, permits instructors to encourage free-flowing, life-like conversations as "participants outside the class community may help shape the learning, making it more authentic" and thereby real. They also note that this allows "learners to be part of a 21 st century community that uses technology for learning together while remaining interconnected" as 
viewpoints are exchanged, collaboration occurs, clarifications are posted, and resources or experiences are shared. The pragmatic grounding of their study similarly frames the research under discussion in this paper.

\subsection{The Need for This Study}

Studies point to the importance intimacy and immediacy has on social presence (Short, Williams, \& Christie, 1976) both in face-to-face and online learning environments and how it potentially impacts students' perceived positive learning experience in online courses and their course satisfaction (Mackey \& Freyberg, 2010). However, fewer studies have examined perceptions of the online learning environment by learners through the lens of gender. Further, case studies have been reported describing how using Twitter interactions in the classroom may enhance student learning and contribute to student satisfaction; however, there have been no studies testing how encouraging specific communicative actions (strategic, normative, constative, and dramaturgical actions) through social media tools may facilitate student course engagement and perceptions of enhanced learning. Further, it remains unclear whether ensuring the presence of these communicative actions influences social presence, rapport, learner perception of participation in a social learning community, the tool's impact on learning in this community, and whether learners perceive the online social learning community differently by gender.

\subsection{Purpose of This Study}

This design-based research project (Barab \& Squire, 2004) sought to employ a single social media tool to help support the development of a positive, online communal and social space to support and facilitate student learning. This was expected to result from increased understanding of global policy issues that would emerge from interactive, argumentative communicative discourse towards intersubjective or shared understanding. The design intervention was supported by Learning and Teaching as Communicative Actions theory (LTCA) (Warren \& Stein, Warren et al., 2010). This theory provided a framework for designing communicative learning with Twitter as we sought to understand the effectiveness of course communication and discourse within the realm of real world learning in a networked, global world.

A mixed methods convergent data-validation design was used that included both quantitative and qualitative strands. The researchers gathered both strands simultaneously through a survey instrument. Consequently, the researchers were able to give each strand equal priority, analyze each separately, and then compare, contrast, and synthesize finding in the merging stage. As described by Creswell and Plano Clark (2011), the rationale for this design is that it allows researchers to "validate or corroborate quantitative scales" (p.73). The sample size in this study was small - thirteen students. Thus, the convergent data-validation design provided the opportunity to validate the quantitative results.

\section{Literature}

Social networking tools are networking tools that allow near synchronous online communication at a distance and also collaborative work among participants. These include such tools as Facebook, Twitter, YouTube, Google+, and blogs. These 
applications utilize the Internet-based "cloud" to host their services. Cloud computing involves data generation with software and data residing on a remote host server rather than on the user's computer (Bianco, 2009). Data is shared from this remote cloud server over the network and is available for others to see, share, and comment on. Further, depending on tool, this data can be collaboratively worked on among multiple participants. Social networking tools are increasingly popular among students as they allow for free-flowing communication that is not only strategically focused on learning assignments, but is often also social in nature.

Learning supported through social networks and digital communications has grown as educators have experimented with tools such as Twitter. Such tools allow instructors to easily test how these tools may provide innovative teaching methods that enhance classroom communication and build a sense of community (Parry, 2008), but also permit instructors to reach-out to students that otherwise might not get their voices heard (Rankin, 2009). Further, work has been done recently to use the tool to support the development of CoPs through social means (Dunlap \& Lowenthal, 2009a; Dunlap \& Lowenthal, 2009b), while also allowing for the development of environments that allow for learning through research on how we use these tools to communicate (Honeycutt \& Herring, 2009; Boyd, Golder, \& Lotan, 2010).

Originally referred to as a micro-blog, Twitter is a "real-time information network" (Twitter, 2011). Users share short updates up to 140 characters, exchange short direct messages with other users, comment and re-post interesting tweets from other users, share pictures, video, and Web links. The global community of Twitterers allows participants to stay connected with their existing followers and attract new followers. In educational settings, Twitter allows instructors and learners "to reach, follow, and share information with and from a wide group of experts in the field of their interest" (Wakefield \& Warren, 2012).

Working collaboratively online, discussing, and sharing resources may help students get to know each other better informally and open up more than in the classroom setting. Anderson and Haddard (2005) found that, compared with face-to-face settings, "females experienced greater perceived deep learning" when learning online. Participants noted that they were better able to make their voice heard online than in a classroom and that this contributed to their "greater perceived deep learning." Having "a sense of who everyone is as real people" (Palloff \& Pratt, 2007, p.107) and being able to relate to one another (Gunawardena, 1995) in a mediated environment while interacting with one another are contributing factors to social presence. As coined by Short et al. (1976), social presence is a "quality of the communications medium itself" (p.65). They argue that certain mediums are better at allowing presence to exist; for instance, television should not cut visual social cues from the receiver. However, this claim has since been questioned by other researchers (Gunawardena, 1995; Tu, 2002) who argue that the quality of a CMC can be perceived equal to, or stronger than, communication in face-toface meetings where social cues such as body language and facial expressions are present.

Social presence has been positively correlated with perceived learning (Richardson \& Swan, 2003; Lowenthal, 2009) and course satisfaction (Richardson \& Swan, 2003; Gunawardena \& Zittle, 1997). Another factor associated with social presence is perceived interaction (Gunawardena, 1995; Kim, Kwon, \& Cho, 2011). Wakefield and Warren (2012) have recently argued that interactivity in CMC is a choice actors take and that "(when) taken, may result in social connections." Thus, learners may or may not realize that their action may generate positive social connections. Further, others involved in communicative transactions may opt out of these connections without 
understanding the impact their non-participation has on their learning community. Some students may be uncomfortable with such communication, while others may understand, but seek to transgress against established norms for personal reasons (Wakefield \& Warren, 2012). When actors engage in social interaction, that action strengthens the potential sense of being there together with other learners - a sense of being part of a social community. Transgression and failure to participate limits the effectiveness of communicative actions taken by learners. Instructors, moderators, and participants in CMCs all help acculturate social presence (Gunawardena, 1995; Tu, 2002).

The literature reveals confounding findings on research on males and females learning in computer-mediated environments. Some studies have favored increased learning in males, others have favored females, while still others report no statistically significant gender differences. For example, Barrett and Lally (1999) found that males in an online course environment were more socially active and wrote more than females. By contrast, Anderson and Haddard (2005), as already mentioned, found that females felt they learned more deeply online when compared with face-to-face settings. Research by Ory, Bullock, and Burnaska (1997) found both genders made similar use of an online learning environment and that gender played no role. An examination of Twitter as learning environment should shed light on the usefulness of the tool to support communicative actions geared towards learning and help the field better understand whether there are differences in the role discourse plays for males and females in this online setting. In the United States, demographic studies indicate that fifty-six percent of Facebook users are women (Smith, 2010) and fifty-five percent of Twitter users are female (Quantcast, 2010, June). According to Smith (2010), this trend indicates that women are becoming more interested in the use of technology and social media, at least in non-education contexts.

\section{Theoretical Framework}

\subsection{LTCA Theory}

Clark (1994) admonishes us that media cannot influence learning. We fully acknowledge that using technology tools such as Twitter in a course cannot directly improve learning outcomes. However, Web 2.0 tools allow for increased discourse among learners and facilitators; thus, Twitter and similar tools should afford learners with opportunities and a means for engaging in increased discussion centered on course topics. If students take advantage of such opportunities, this additional time spent on learning tasks should result in increases in learning. This claim is supported by Bloom's (1968) assertion that learning occurs best when there is excellence in instruction and learners are given sufficient time on task. By approaching the integration of Twitter in a course as a means of fostering communicative actions among learners and instructor, we increase learning not through the tool, but through increased access to non-classroom educational resources and the professional discourse it provides.

In keeping with this perspective, Twitter was employed in a course on Global Policy Issues within the pragmatic framework of Learning and Teaching as Communicative Actions Theory (LTCA) (Warren \& Stein, 2008; Warren et al., 2010). This theory builds on German sociologist and pragmatist Jürgen Habermas' Theory of Communicative Action (TCA) with the goal of comprehending and furthering the usefulness of human understanding towards a goal (Habermas 1981/1984, Habermas, 1998). As originally outlined by Warren and Stein (2008), LTCA theory seeks to improve 
human communication towards instructional and learning goals. Learning constructs in this theory come from Habermas' four communicative actions: normative, strategic (teleological), constative, and dramaturgical actions (Warren et al., 2010). LTCA theory holds that "learning and teaching emerge from understanding and fostering learning activities that allow for" all four communicative actions together to guide the learner and instructor towards reaching and improving understanding through effective communicative actions (Warren et al., 2010).

Within this pragmatic view, we claim that learning experiences should be designed not from only a single perspective such as those put forth by Skinnerian Behaviorists or separately by social constructivists. Instead, a rational curriculum recognizes the complexity of any learning experience. Thus, academic tasks, assessments, and discourses should be designed to encourage understanding from myriad perspectives. Learning stems from such activities and, principally, from the discourses that attend each.

In educational settings, the first goal of an educational communicative action is to transmit normative communicative actions that provide the rules and guidelines for how to behave and participate in a class setting to reach given learning goals. These communicative actions conform to societal understandings that are generated through past experiences (Warren, 2011) and discourse among participants in an educational system. They also include negotiations within the social world of which the participants are part (e.g. school, community, etc.) and are accepted through constructed consensus among all participants stemming from discourse. If communications are instead directives to behave in a certain manner and are entirely administrative or provided by those in power (i.e. instructor, principal), then they are strategic. Normative actions are continuously negotiated as social realities change. In the classroom, these communications are often directives placed in the course syllabus that give students behavioral guidance, as well as rules that have been generated over time in response to student and instructor interactions during previous instances of the course. For instance, communicated information often includes norms regarding what a student should do in order to receive a certain grade. In our study of an online classroom setting in which communicative actions were employed, students were asked to sign-up for Twitter and follow the instructor's course account as a graded assignment. Normative actions provide learners with "two worlds, the objective and the social world" (Habermas 1981/1984, p.89). It is through these worlds that students challenge and engage in the construction of the legitimacy, norms, and interests (Warren, 2011) by which learning goals may be reached. These stem from societal expectations of fairness and related legal rules.

Another goal in the educational setting is to transmit objective, empirical knowledge to students. Such knowledge includes traditionally accepted truths generated through social consensus. In the current educational and political climate, these are often comprised of strategic communicative actions. These often include textbook truths - the socially agreed upon, verified, and validated objective knowledge that can only be accepted or rejected by the hearer/reader. For example, in our study students were asked to respond to directives and questions posted over the course Twitter account. This included directions to complete weekly readings of articles and thereafter tweet important concepts they learned from this reading. These tweets were shared with the Twitter community at large through public posts and were therefore open to wide critique. If the learner accepted such a strategic speech act, then she completed the assignment as specified. When given by an instructor, strategic actions are believed to be useful to the student; if accepted, the student tacitly agrees to the validity of this claim. Should the student choose not to complete the assignment, they reject the validity of the directive. In today's classroom, strategic actions are the commonly employed and accepted truths. 
Table 1. LTCA Instructional design principles

\begin{tabular}{|c|c|c|}
\hline $\begin{array}{c}\text { Communicative } \\
\text { Action }\end{array}$ & $\begin{array}{c}\text { Instructional Design } \\
\text { Principle }\end{array}$ & Design Direction \\
\hline Normative & $\begin{array}{l}\text { Allow students an opportunity to } \\
\text { negotiate norms and classroom rules } \\
\text { that support their learning experiences. } \\
\text { Students and instructor should construct } \\
\text { norms that will guide effective } \\
\text { communication in which all members of } \\
\text { the classroom may fairly and respectfully } \\
\text { critique claims to truth and knowledge. }\end{array}$ & $\begin{array}{l}\text { When preparing learning experiences, include and } \\
\text { model initial rules for behavior and discourse, but } \\
\text { allow for whole class negotiation and modification of } \\
\text { these norms early and regularly in response to } \\
\text { expressed need. The instructor may start with the rule } \\
\text { that no one may speak without raising their hand and } \\
\text { being recognized by the teacher. However, through } \\
\text { negotiation, students may instead establish conditions } \\
\text { under which they may speak without the instructor's } \\
\text { permission. }\end{array}$ \\
\hline Strategic & $\begin{array}{l}\text { Instructor provides knowledge of or } \\
\text { access to shared, socially validated facts } \\
\text { that can be communicated by an } \\
\text { instructor or technological tool including } \\
\text { textbooks, websites, and other } \\
\text { repositories of reified knowledge. }\end{array}$ & $\begin{array}{l}\text { When designing instruction, include activities that } \\
\text { communicate basic, socially validated knowledge to } \\
\text { give students a framework for understanding, } \\
\text { discourse, social and relative knowledge construction, } \\
\text { and other future learning experiences. That } \\
\text { knowledge which comes to schools from the state has } \\
\text { been subjected to numerous challenges to claims to } \\
\text { truth prior to inclusion in state standards. While some } \\
\text { may be faulty, they provide a starting point for shared } \\
\text { understanding and a place to begin critique of validity. }\end{array}$ \\
\hline Constative & $\begin{array}{l}\text { Give opportunities for students to engage } \\
\text { in critical discourse centered on } \\
\text { understanding truth claims and } \\
\text { knowledge put forth by peers, instructor, } \\
\text { textbooks, etc. Further, they have their } \\
\text { own claims to truth and knowledge } \\
\text { critiqued and challenged towards a larger } \\
\text { goal of constructing or acquiring valid } \\
\text { knowledge towards making future } \\
\text { change. }\end{array}$ & $\begin{array}{l}\text { Include specific opportunities for students to critique } \\
\text { existing claims to knowledge and truth from texts, } \\
\text { instructor, peers, and other sources of reified } \\
\text { knowledge. Allow students to construct their own } \\
\text { claims to truth and knowledge and allow them to be } \\
\text { tested for validity by peers, instructor, and, if } \\
\text { applicable, experts. As put forth in social } \\
\text { constructivist views, communication among and } \\
\text { between students is an effective means of } \\
\text { constructing knowledge. However, any knowledge } \\
\text { emerging from this discursive process must also be } \\
\text { open to the crucible of critique in order to test its } \\
\text { validity. }\end{array}$ \\
\hline Dramaturgical & $\begin{array}{l}\text { Make available chances for students to } \\
\text { safely express their personal identities, } \\
\text { passions, and other internal, relative, or } \\
\text { subjective truths and knowledge, which } \\
\text { are open to respectful critique through } \\
\text { discourse with peers, instructor, and oth- } \\
\text { ers. }\end{array}$ & $\begin{array}{l}\text { Design instruction that allows students opportunities } \\
\text { for safe personal expressions of identity - expressive } \\
\text { understanding of the subject, while allowing for } \\
\text { minor critique. While a student's song is an } \\
\text { expression of personal identity and truth, it remains } \\
\text { subject to validity critique through discourse in social } \\
\text { settings, as when critics review a Broadway musical. }\end{array}$ \\
\hline
\end{tabular}

Constative communicative action involves dialogue between interlocutors through which, over time, accepted claims to truth shift. Changes to such intersubjective agreements depend on the evidence set forth by speaker and hearer in dialogue. Within the classroom, this interaction is one in which a give and take of validity claims takes place, meaningful communication occurs, and arguments are shared that contribute to future learning and change. For example, students may make claims about the validity of an assigned reading or an ill-structured problem provided by their teacher or peers. Each participant then provides arguments supporting meaningful dialogue with the instructor towards a goal of establishing agreed upon truth claims. Each must be sufficiently supported with evidence so that participants (both speakers and hearers) agree that they are acceptable premises for prefacing future discourses. Such dialogue provides learners 
voice in a sociocultural setting and allows for the construction of knowledge through discourse and negotiations (Habermas, 1981/1984).

Finally, dramaturgical communicative actions allow self-expression of lifeworld (lived -in world by the individual). These lifeworld experiences provide the learner with access to two worlds: the subjective inner world through which the speaker may express personal identity and understanding, and the objective world through utterances (Habermas, 1981/1984, p. 93). Dramaturgical actions are thus expressions of internal lifeworld - the individual's identity and experiences - and may be expressed in an artistic way such as through painting, graphic design, poetry, or expression in writing papers posted for respectful peer review (Wakefield \& Warren, 2012). Dramaturgical communicative actions thus provide an opportunity to test the validity of a learner's internal understandings through critique in the objective world. In Bloom's (1968) framework, dramaturgical action may be compared to time spent on task and application of the learned material as a synthesis of multiple learning experiences. Table 1 provides both instructional design principles and examples of how each type of communication would be implemented in classroom settings.

We argue that communicative actions provide both instructors and students with opportunities to meaningfully communicate towards a goal of acquiring or constructing understanding. Habermas explains discourse as a give and take of validity claims that forces interlocutors to presume there will emerge recognition and acceptance or consensus after these reflective speech acts (Habermas, 1981/1984, p.42). The importance of discourse is evident as Habermas argues that there is no alternative to communication and discourse in modern societies for resolving conflicts and reaching consensus (Finlayson, 2005). Thus, employing the lens of LTCA theory enables learning through the use of Twitter.

\subsection{Global Policy Issues - Course Design}

Offered online for the first time, the course was designed to help students learn the basics of policy analysis by exploring many pressing, strategic global policy issues through exploration, group collaboration, topical discussion, and synthesis of new understandings from the textbook and research papers. Strategic communicative actions were provided students through the syllabus, reading a course book and research papers about the causes and solutions to global problems such as military and other conflicts, security, human rights, poverty, hunger, women's rights, disease epidemics. Students were given opportunities to practice different approaches to analyzing problems and suggesting possible solutions through constative communicative actions in the form of discourse with peers and instructor. They also articulated their understandings through dramaturgical actions - their expressions of understanding - lifeworld - through tweeting, writing, and reviewing peer papers. Twitter was employed as a tool to support instructor and students' communicative actions, share interesting content for further discussion, and foster a real-world interactive online community that is often difficult to develop in a learning management system-guided course.

As class began, students were provided with a strategic communicative direction to sign up for a Twitter account and follow Tweets posted by the instructor on the course account. To aid them in the process and the technology, several videos from YouTube and a manual were provided. Twitter was a graded course component and students acclimated to the tool during ungraded introduction weeks, allowing participants to familiarize themselves with the environment and tweet without grade consequences. A grading rubric for Twitter communication was shared in the learning management system 
(LMS) during week three. Twitter grading periods were: Period 1 (weeks 3-6), Period 2 (weeks 7-10,) Period 3 (weeks 11-16). Students could earn 10 points per grading period. The total course grade for Twitter communication in this course was thus 30 points of a possible course total of 400 points.

Prior to establishing constative communicative action through student Twitter discussions, the instructor provided strategic communicative actions in the form of directions to use the technologies and normative communications regarding appropriate argumentation and truth claim critique as well as proper online interaction or "netiquette." Throughout the semester constative discourse was encouraged in this course not only through Twitter use but also on the LMS discussion board through various challenging topics with their inherent, disputed truth claims. The instructor tweeted at least once a week and asked open-ended questions often stemming from weekly readings, such as "tweet one important idea from chapter 5;" or "what do you think about the issue in chapter 6 page 68." The instructor did not respond to students' dramaturgical tweets (i.e. their thoughts on the readings), as she wanted the students to engage in free-flowing, non-moderated discussion. Her notion was that if she started making comments on students' tweets, students might resist communicating their thoughts freely due to power relationships in which they viewed her as the arbiter of truth due to her role as instructor. She did, however, respond to specific course related student questions over Twitter.

\section{Research Methods}

\subsection{Setting}

This study took place at a university in the southwest United States with a population of about 15,000 students and it currently supports a large number of undergraduate students. The Carnegie Foundation classifies it as a research university with high research activity. The campus is situated in a suburban neighborhood in a large metropolitan area.

\subsection{Participants}

The survey instrument was completed by thirteen $(n=13)$ participants enrolled in an undergraduate course in Global Policy Issues that utilized Twitter as a communication tool for classroom discussion as a graded course component. Seven students were females $(n=7)$ and six males $(n=6) .69 \%$ of the students had not used Twitter prior to the course.

\subsection{Research Questions}

\section{H1 - To what extent does use of Twitter increase student's engagement in a course?}

It was hypothesized that the strategically communicated direction to participate in the interactive environment that provides for a free-flowing constative communication would provide students rapid feedback and strongly contribute to student engagement and participation.

H2 - To what extent does Twitter help students understand the course content and assigned readings better? 
It was hypothesized that providing normative communication (rules and guidelines for student's actions) students would perceive the interactive environment with rapid feedback among participants as a factor contributing to increased understanding of readings as they would employ constative communication and dramaturgical communication to discuss truth claims made by authors and share resources to support their arguments.

H3 - To what extent does communication over Twitter promote social presence (interactive learning/participation/sense of being there) amongst students and to what extent are there gender differences, if any, in this perception?

It was hypothesized that social presence would be promoted strongly as students communicated in near real-time with peer and that female students would feel a stronger sense of community than males.

\subsection{Instrumentation}

A new online survey instrument developed specifically for the purpose of this study was shared with students at the end of the semester containing both closed and open-ended questions (Figure 1).

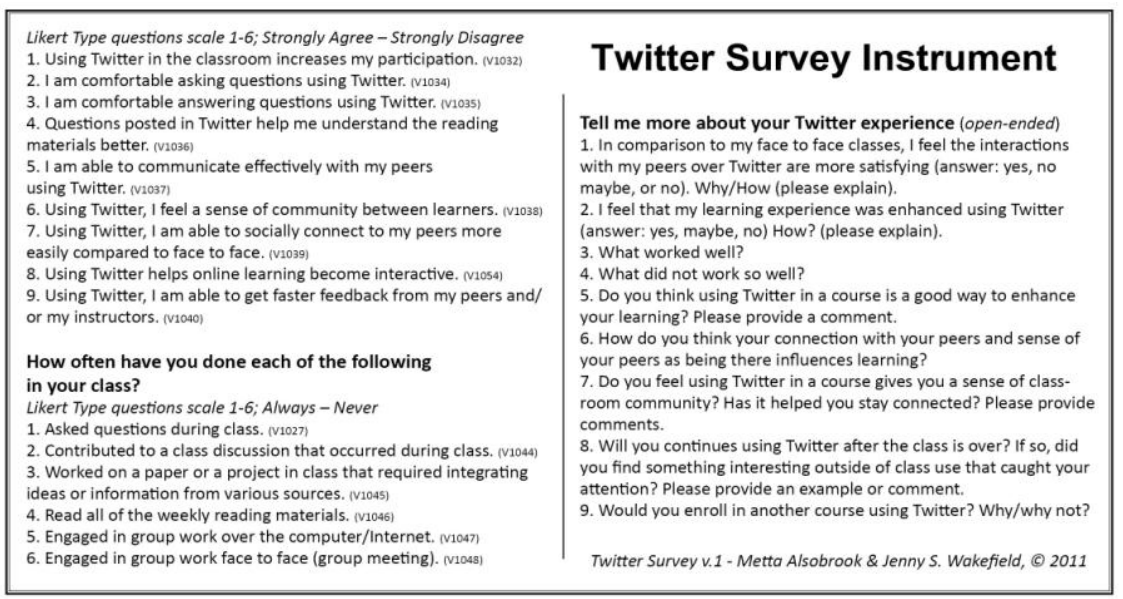

Figure 1. Twitter Survey Instrument v1

As described in the introduction, a mixed methods convergent data-validation design was utilized. The survey instrument consisted of fifteen Likert type scale items and nine open-ended questions. The mixed methods design allowed the researchers to separately analyze the data strands and thereby treat them equally before mixing the results in the interpretive stage (Creswell \& Plano Clark, 2011). Timing of the strands was concurrent. Quantitative strands were analyzed using IBM ${ }^{\circledR}$ SPSS $® 19.0$ and qualitative strands were analyzed using Herring's (2004) Computer-Mediated Discourse Analysis (CMDA) procedure. 


\section{Results}

\subsection{Scales}

Face validity of the survey instrument indicated two separate scales. Reliability analysis of all fifteen items yielded a total Cronbach's Alpha $\alpha .87-\mathrm{a}$ "very good" according to DeVillis (1991) psychometric guidelines. The quantitative strand was further analyzed for construct validity using exploratory factor analysis, multidimensional scaling (ALSCAL), and hierarchical clusters. The analysis indicated two pure factors, one crossover, and one outlier variable (factors considered 'pure' based on the initial face validity of the instrument). The outlier was excluded from the resulting scales and corresponds to "Engaged in group work face-to-face" (V1048). The scale reliability for the resulting three scales (Table 2), for subjects completing this instrument, indicated a high degree of internal consistency with Alpha values (Social Learning Community) excellent $\alpha .93$, (Comfortable Online Communicator) very good $\alpha .81$, and (Engaged Student) very good $\alpha .80$.

Table 2. Scale items and t-test

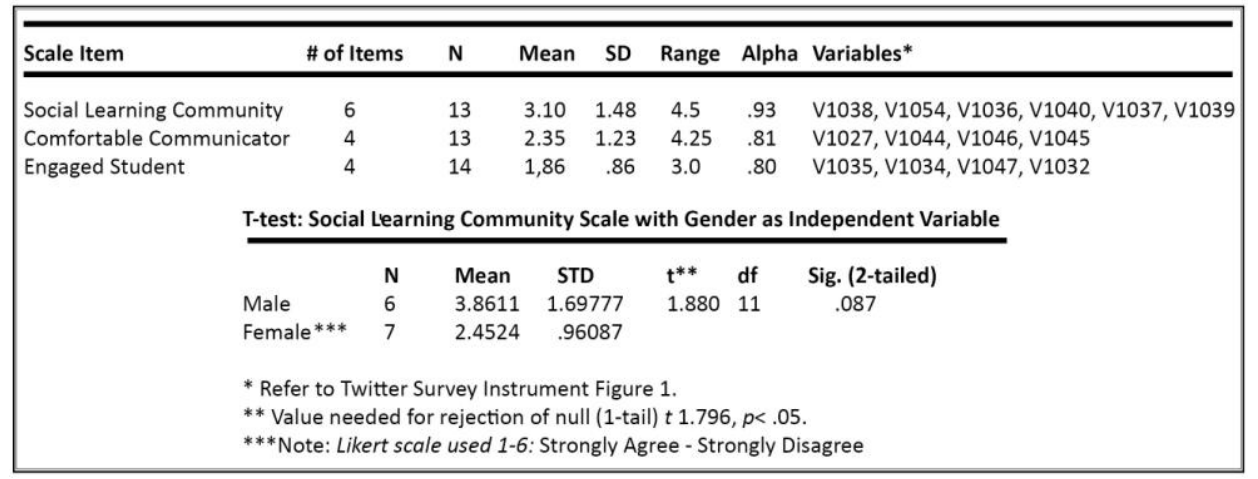

Pearson correlations were explored. Fast feedback correlated significantly $p<.01$ (one-tailed) with interactive learning, sense of community, communicate effectively, and helps understand readings indicating a trend toward student perception of the environment as a free-flowing interactive environment where they could engage with one another and with the course content. Individual variable correlations are shared in Table 3 .

Interactive learning correlated very strongly with helps understand readings and with fast feedback. Both these correlations are significant at the $p<.01$ level (one-tailed). The variables sense of community, interactive learning, and helps understand readings are the top three loaders in the Social Learning Community scale. This scale correlated significantly one-tailed with the Comfortable Online Communicator scale $p<.05$ indicating a tendency toward students' experiencing communication being a significant and important component of this social learning community. A noticeable relationship is further found between the variables sense of community and interactive learning. These correlate $\left(\mathrm{r}^{2} \mathrm{xy}=.90\right)$ with $90 \%$ shared variance making this the strongest indicator for social learning community in this group indicating how communication through the use of Twitter very strongly promotes social presence. A t-test with gender as independent variable and a table look-up revealed a statistically significant difference in perception towards the interactive social learning community favoring females stronger perception, $p<.05$, in this small sample, as indicated in Table 2 . 
Table 3. Correlations of variables (excluding v1048 - the outlier)

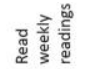

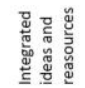

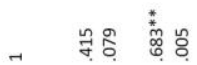

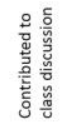

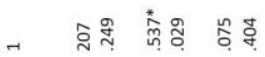

喜 -

总

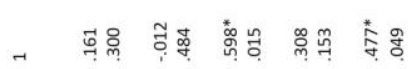

喜题

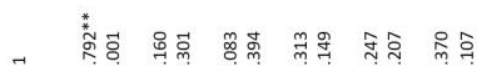

ำ

先

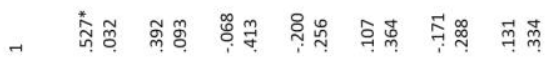

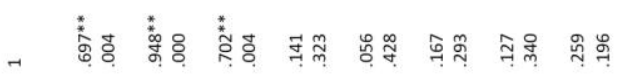

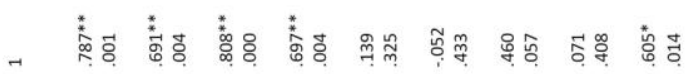
蒿

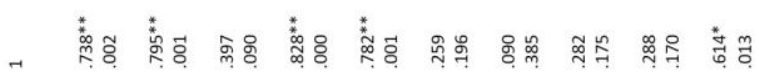

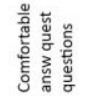

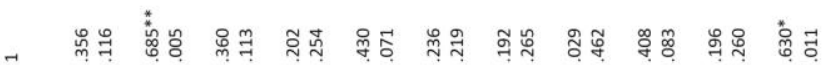

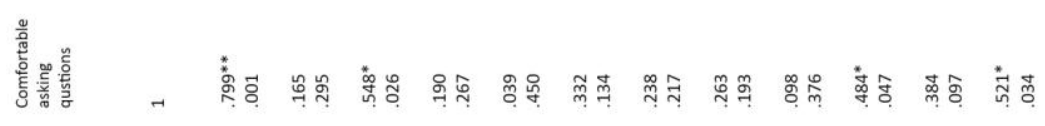

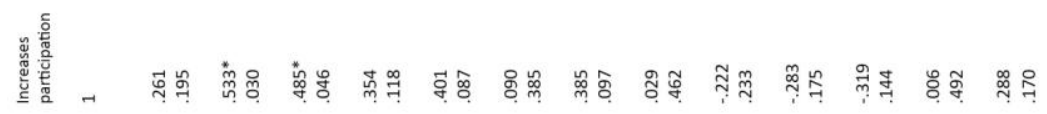

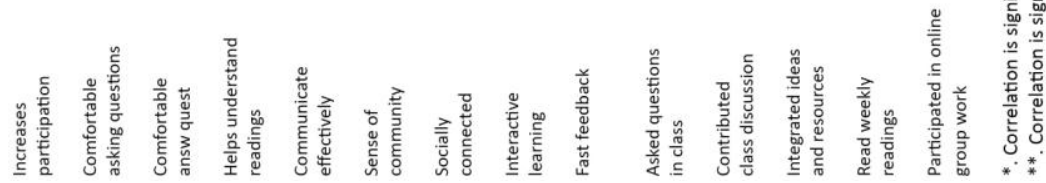




\subsection{Qualitative Findings}

Student's utterances were entered into Microsoft Excel and coded. Codes were merged into larger categories from which three themes emerged during discourse amongst the researchers. The codes and categories were limited by the open-ended survey questions. Emerging themes tied either directly to the types of communicative actions that the design sought to foster or to student perceptions of Twitter as a pedagogical tool. The questions are presented in Figure 1.

Table 4 presents findings from the closed-ended questions used to introduce the qualitative, open-ended responses.

Table 4. Student responses to qualitative open-ended questions

\begin{tabular}{|c|c|c|c|c|}
\hline $\begin{array}{l}\text { Question } \\
\text { No. }\end{array}$ & & Yes & No & $\begin{array}{l}\text { Maybe/No } \\
\text { response }\end{array}$ \\
\hline 1 & $\begin{array}{l}\text { In comparison to my face-to-face classes, I feel the interactions with } \\
\text { my peers over Twitter are more satisfying (answer: yes, no maybe, or } \\
\text { no). Why/How? (please explain) }\end{array}$ & 5 & 5 & 3 \\
\hline 2 & $\begin{array}{l}\text { I feel that my learning experience was enhanced using Twitter (an- } \\
\text { swer: yes, maybe, no) How? (please explain) }\end{array}$ & 5 & 5 & 3 \\
\hline 5 & $\begin{array}{l}\text { Do you think using Twitter in a course is a good way to enhance your } \\
\text { learning? Please provide a comment. }\end{array}$ & 7 & 6 & \\
\hline 7 & $\begin{array}{l}\text { Do you feel using Twitter in a course gives you a sense of classroom } \\
\text { community? Has it helped you stay connected? Please provide com- } \\
\text { ments. }\end{array}$ & 6 & 6 & 1 \\
\hline 8 & $\begin{array}{l}\text { Will you continue using Twitter after the class is over? If so, did you } \\
\text { find something interesting outside of class use that caught your atten- } \\
\text { tion? Please provide an example or comment. }\end{array}$ & 4 & 7 & 2 \\
\hline 9 & Would you enroll in another course using Twitter? Why/why not? & 7 & 3 & 3 \\
\hline
\end{tabular}

Student responses to yes/no/maybe questions indicate a divided perception of Twitter as a tool. For those stating they had a positive (yes) or benign (maybe) experience, their general perception of the tool and its use to support learning indicated that it is a valuable addition to the classroom, fostering useful constative communication among student participants furthering their learning. Those that expressed a negative experience, tended to use the words "horrid," "awful," and "confusing" to frame the use of Twitter for learning. The open-ended responses shed light on why student responses were mixed and helped reveal students' particular experiences. Relevant codes with more than two supporting student utterances are presented in Tables 5 and 6.

\section{Positive codes}

Table 5 indicates codes in which students responded positively to the use of Twitter and the communicative actions they support. Table 6 includes negative responses.

The six positive codes reflect either strategic interactions with the instructor in which students receive direction to act, feedback on their dramaturgical products, or supportive constative communications engaging students in peer argumentation or interactions geared towards learning goals.

Of interest in the qualitative strand was the number of positive utterances regarding Twitter made by the women versus the men. For example, on Question 1 
asking whether their online interactions with peers were more satisfying, all that answered affirmatively were female and on Question 2, four found Twitter enhanced their learning vs. only 2 male. This positive view of Twitter as indicated by their responses may help explain the quantitative data that noted a statistically significant positive female perception of the tool to support the social learning community. The majority of participants that stated they would continue to use Twitter or a similar social media tool in the future were female and those stating they would be willing to participate in future courses using Twitter were largely female ( 6 female/ 2 male). While both genders expressed frustration with the 140 character limits, six of seven females noted that their main concern was that it prevented them from writing full thoughts and their posts might be misconstrued by peers.

Table 5. Positive responses regarding use of Twitter for learning

\begin{tabular}{|c|c|c|c|c|c|c|}
\hline $\begin{array}{l}\text { Positive Twitter } \\
\text { Codes }\end{array}$ & $\begin{array}{l}\text { Talk freely } \\
\text { online/know } \\
\text { more about } \\
\text { each other/ } \\
\text { More casual }\end{array}$ & $\begin{array}{l}\text { Fast / } \\
\text { short } \\
\text { feedback }\end{array}$ & $\begin{array}{l}\text { Reading } \\
\text { instructor } \\
\text { tweets / } \\
\text { instructions }\end{array}$ & $\begin{array}{l}\text { Tweeting/ } \\
\text { following } \\
\text { instructor }\end{array}$ & $\begin{array}{l}\text { Good discussions } \\
\text { occurred / } \\
\text { interactive / } \\
\text { learn about } \\
\text { opinions }\end{array}$ & $\begin{array}{l}\text { Learn through } \\
\text { collaborative } \\
\text { interaction / } \\
\text { discussion } \\
\text { /arguments }\end{array}$ \\
\hline \multicolumn{7}{|c|}{$\begin{array}{l}\text { Type of communicative } \\
\text { action enabled }\end{array}$} \\
\hline Strategic & & Yes & Yes & Yes & & \\
\hline Constative & Yes & & & Yes & Yes & Yes \\
\hline Normative & Yes & & & & & \\
\hline Dramaturgical & & Yes & & & & \\
\hline
\end{tabular}

\section{Negative codes}

While many codes emerged from individual students, there was little consensus as to the value of Twitter as a tool for learning. Table 6 contains nine codes that indicated negative experiences or perceptions expressed by students as well as communicative actions we see as being limited by the tool.

Table 6. Negative responses regarding use of Twitter for learning

\begin{tabular}{|c|c|c|c|c|c|c|c|c|c|}
\hline $\begin{array}{l}\text { Negative Twitter } \\
\text { Codes }\end{array}$ & $\begin{array}{l}\text { Limited } \\
\text { interaction } \\
\text { with peers }\end{array}$ & $\begin{array}{l}\text { Lecture / in- } \\
\text { person more } \\
\text { interactive } \\
\text { better pref. }\end{array}$ & $\begin{array}{l}\text { Uncomfortable } \\
\text { sharing Twitter } \\
\text { / privacy issues }\end{array}$ & $\begin{array}{l}\text { Too few } \\
\text { characters }\end{array}$ & $\begin{array}{l}\text { New } \\
\text { Twitterer } \\
\text { problems }\end{array}$ & $\begin{array}{l}\text { Limited use } \\
\text { / interaction } \\
\text { by peers }\end{array}$ & $\begin{array}{l}\text { Confusing } \\
\text { environment } \\
\text { / Difficult to } \\
\text { follow }\end{array}$ & $\begin{array}{l}\text { Prefer } \\
\text { other } \\
\text { tool }\end{array}$ & $\begin{array}{l}\text { Did not } \\
\text { like } \\
\text { Twitter }\end{array}$ \\
\hline \multicolumn{10}{|c|}{$\begin{array}{l}\text { Type of communicative } \\
\text { action limited }\end{array}$} \\
\hline \multicolumn{10}{|l|}{ Strategic } \\
\hline Constative & Yes & Yes & Yes & & & Yes & Yes & & \\
\hline Normative & & & Yes & & & & & & \\
\hline $\begin{array}{l}\text { Dramaturgical } \\
\text { Instrumental }\end{array}$ & & & & $\begin{array}{l}\text { Yes } \\
\text { Yes }\end{array}$ & Yes & & Yes & Yes & \\
\hline
\end{tabular}

Note that a type of communicative act we have not framed thus far emerges as a central challenge. Discussed and debated at length by Gadamer and Habermas (Bernstein, 1983), the idea of techne, also known as instrumental communication or reasoning, stems from the domain of work or craft. It is that of instrumental or goal-oriented reasoning and action. Since technologies are mainly concerned with the production of specific products, the means and ends remain constant. Such actions involve choosing strategies, techniques, and/or tools deemed appropriate to a given situation; in this case, learning. For students, 
the idea is that once a tool is learned (i.e. Facebook), there is no need to learn another tool or its associated use; instead, they can merely use the skills they already have and being forced to use another becomes tedious or frustrating.

Viewing Twitter as a tool, some questions clearly address whether students see it as an appropriate means for achieving their own or the goals of the class/educational system (i.e. did you learn the reified knowledge that is valued.) The remaining qualitative questions examined or expanded upon whether students viewed Twitter as improving their learning, whether they perceived it positively or negatively impacting a sense of community, and whether they would continue to use the tool in the future or be willing to participate in courses that leverages Twitter to support communications. While many of the codes appear negative, the majority of these indicate problems that have little to do with the tool. These were either technological problems stemming from lack of familiarity with the tool or a failure of students to participate in the Twitter supported community. However, the structure of Twitter itself with its 140-character limit was problematic for some students in reaching learning goals.

Also of note is that the majority of the negative sentiments underlying these codes came from men in this course. With one exception, the majority of the males viewed Twitter as not enhancing their learning, stating that they struggled to learn to use the tool, were frustrated by lack of peer discourse, and one-third stated that they saw no educational value to using it. However, some males viewed Twitter as a positive tool for engaging in constative or argumentative discourse. They noted that it enabled them to reach consensus with peers through engaging in useful discussions.

\section{Categories}

These identified codes yielded several categories that are largely tied to the types of communicative actions that Twitter either was seen by students to support or not. These are presented in Table 7. These categories yielded two main themes reflective of the mixed student perceptions of Twitter as a tool to support learning.

Table 7. Emergent categories

\begin{tabular}{|c|c|c|c|c|c|c|c|c|}
\hline \multirow{2}{*}{\begin{tabular}{|l} 
Category \\
$\begin{array}{l}\text { Negative or } \\
\text { Benign Codes }\end{array}$
\end{tabular}} & \multicolumn{5}{|c|}{ Structural Limitations } & \multicolumn{3}{|c|}{ Personal Preference } \\
\hline & $\begin{array}{l}\text { Limited } \\
\text { interaction } \\
\text { with peers }\end{array}$ & $\begin{array}{l}\text { Too few } \\
\text { characters }\end{array}$ & $\begin{array}{l}\text { Confusing } \\
\text { environment } \\
\text { / Difficult to } \\
\text { follow }\end{array}$ & $\begin{array}{l}\text { Uncomfortable } \\
\text { sharing } \\
\text { Twitter / } \\
\text { privacy issues }\end{array}$ & $\begin{array}{l}\text { New } \\
\text { Twitterer } \\
\text { problems }\end{array}$ & $\begin{array}{l}\text { Lecture / in } \\
\text { person more } \\
\text { interactive } \\
\text { better pref. }\end{array}$ & $\begin{array}{l}\text { Prefer } \\
\text { other } \\
\text { tools (e.g. } \\
\text { Facebook }\end{array}$ & $\begin{array}{l}\text { Did not like } \\
\text { Twitter as } \\
\text { tool }\end{array}$ \\
\hline Category & \multicolumn{3}{|c|}{$\begin{array}{l}\text { Supports Constative / Normative } \\
\text { Communication }\end{array}$} & \multicolumn{5}{|c|}{ Supports Strategic Communication / Instructor Direction } \\
\hline Positive Codes & $\begin{array}{l}\text { Talk freely } \\
\text { online / } \\
\text { know more } \\
\text { about each } \\
\text { other / } \\
\text { More } \\
\text { casual }\end{array}$ & $\begin{array}{l}\text { Good } \\
\text { discussions } \\
\text { occurred / } \\
\text { interactive } \\
\text { / learn } \\
\text { about } \\
\text { opinions }\end{array}$ & $\begin{array}{l}\text { Learn through } \\
\text { collaboration } \\
\text { interaction / } \\
\text { discussion } \\
\text { / arguments }\end{array}$ & $\begin{array}{l}\text { Reading inst } \\
\text { tweets / inst }\end{array}$ & $\begin{array}{l}\text { uctor } \\
\text { uctions }\end{array}$ & $\begin{array}{l}\text { Tweeting / fol } \\
\text { instructr. Twe }\end{array}$ & $\begin{array}{l}\text { wing } \\
\text { ts }\end{array}$ & $\begin{array}{l}\text { Fast / short } \\
\text { feedback }\end{array}$ \\
\hline
\end{tabular}

\section{Thematic outcomes}

\section{Theme 1. Twitter can increase communicative learning actions outside of class}

Reflective of the categories, Supports constative/normative communication and Supports strategic/instructor communication direction, Twitter was viewed by around half the respondents as useful for improving learning. They saw this to result of their 
interactions with peers and/or instructors outside of the classroom through the use of Twitter. For example, Anna stated, "Yes, [I was able to] talk more freely because you are not face-to-face" while Kerstin noted that "It is easier to communicate online because you can think about your posts and you don't have to worry about being shy so it is possible that the statement is true." She also stated "It was nice to discuss ideas because you have to have at least a base knowledge to make/agree/disagree with a point." Rebecca reflected Kerstin's sentiment as well: "yes I feel more comfortable responding and being involved in discussion [with Twitter]." These comments indicate that some students in a classroom may not feel free to express their thoughts. Twitter and other social media can function as a means to engage students in constative argumentation or dramaturgical expression when they feel restricted in a face-to-face environment. As these two forms of communication are central to learning in LTCA theory, Twitter becomes an important tool for enabling communications that require revealing oneself in a manner that many find disconcerting, so disengage from such learning activities.

As noted in the theme's title, Twitter can be used to support communicative actions; however, like with most tools, its effectiveness is dependent on student willingness to use it. For example, Rebecca stated that it "makes the class more interactive...[i]t helps us communicate together more" and Jonas indicated that "[s]everal good discussions took place on Twitter during the semester." Roger indicated that it could be useful for certain types of communications that do not require depth of discussion, especially "for...short comments to show we did the reading or conversation." Further, Aileen noted that it fostered a sense of interdependence among students as "It made me work harder so that I didn't disappoint fellow students that I had gotten to know," an indicator that it was useful for reinforcing class norms that support learning. She went on to say that "[i]t helped me stay connected more with the professor than the students." Madison echoed this saying "I like being connected with my peers and I learn from the interaction via discussion postings and group assignments." Jonas also noted that the affiliated "group work was a good way to mesh ideas and write a more well-rounded essay," which was one of the outcomes of the course and indicated a reasonable level of student constative discourse geared towards learning or knowledge construction.

It was also noted that instructor choices regarding how to use the tool can impact student comfort with using Twitter to learn or communicate and may limit participation. Alice noted that, "No we did not really use twitter that much. Plus we were supposed to @ our professor before each interaction which meant that there wasn't much 'privacy' or a place for candid interactions." She further explained that, "We only used twitter for planned interactions which left tweets feeling stiff and overly planned." Communicative actions were sometimes also limited by student willingness to participate. When asked whether they would continue to use Twitter, Rebecca stated that "yes, I found it has intellectual purpose instead of just for celebrities" and Alice concurred saying that "I was already using twitter before this class started and I will continue to use it afterwords (sic)." However, there were an equal number of students that felt the tool is substantially limited for supporting learning, leading to the next theme.

\section{Theme 2. Structural and student preferences restrict Twitter's value to support learning}

As indicated by the categories structural limitations and personal preferences, many students found that Twitter as a tool to support learning was limited or would be better served using a different medium. The primary issue for most students was the 140- 
character limit for communicating with peers and instructor. Taylor stated that it did not enhance his experience due to "limited character responses" and Kerstin replied that "I think the idea of twitter is good; however the limited characters makes it very difficult to explain yourself." Michael reflected this sentiment stating that "if it had more than 140 characters, it could be more useful, but the fact that you have to use \#paw(weeK \#)(sic) there is too little space" (\#paw and week\# here refer to the strategic communication the instructor instituted for hash tags organizing class tweets).

The structure and nature of Twitter also posed challenges. For example, Michael was concerned with the security of Twitter and stated that the structure "made it more confusing for me. I only followed the instructor and the group members that I did projects with. Were twitterers (sic) who weren't students able to access our class material? how secure is all of this. I am a skeptic by nature." The rapidity with which the Twitter feed moved was also noted as a challenge by Allen "This online class was very tough to keep up with" while Taylor noted that it was "quite confusing for some I believe" and Thomas stated that he did not feel it is an appropriate tool for learning "I think twitter was a hassle and was difficult. I wouldn't recommend twitter for a class such as this." He expanded by saying "I don't plan on using twitter [in the future]. I use Facebook. I think twitter is a social network for following celebrities etc. Twitter isn't the ideal place to hold a class discussion. It has its limits." Aileen concurred stating that she "will most likely delete it. I use facebook (sic)" and Michael said "I use facebook to keep up with friends and family. Other than that I do not follow blogs. If I want to know something about anything I look it up and that is about it. Too many things to always try to stay connected to 10 different sites."

Alice, a student that uses and enjoys Twitter outside of class noted, "Twitter works well. This class did not work particularly well with twitter." The structure of Twitter was also noted as a limitation to its usefulness as well for either learning or developing community within the class. Thomas indicated this, saying "Twitter is difficult to follow because everyone is sort of on their own if they don't follow other classmates within the same class. There are no groups and chatrooms (sic) on twitter which make it difficult to effectively communicate with others and develop a sense of community."

Taken as a whole this indicates that the learning activities and the structure of the course were problematic, as noted by Allen: "Twitter was just another thing that had to keep up. TOO many platforms for the class." This overload with technology was coupled with the challenge of group work as stated by Kerstin saying "[i]t was hard to communicate on twitter because of the limited characters. (This is the only reason I gave Twitter harsh results above). I did not like working with a group because I ended up doing everything and it put a time crunch on me getting the work done because I would wait to let my peers contribute which they hardly did." Improving the integration of the tool into the course curriculum while eliminating redundant communication tools or learning activities should then be an important approach for refining Twitter's use as a tool supporting communicative actions geared towards learning.

\section{Discussions}

Our mixed methods convergent data-validation design allowed us to combine hypothesis testing (quantitative findings) and hypothesis generation (qualitative findings) in one study with a small sample of students. Utilizing this design we were able to synthesize complimentary findings and provide a more holistic picture of students' perception from 
use of Twitter technology in an online course as a means of supporting a learning community and encouraging student discourse related to academic topics.

Our study is limited in several aspects: First by the small sample size. Second, we relied on student perceptions that can only provide a snapshot of what may be occurring. For the purpose of our study, however, we were interested in the students' perspective to how LTCA theory and the communicative actions used within the Twitter environment may support and enhance learning and promote community building. We realize that many system, instructor, student, as well as technology factors play a role and may vary per study, thus limiting capture of data similar to ours.

Communication is inarguably an important life skill. The Learning and Teaching as Communicative Actions (LTCA) theoretical framework recognizes such communication as central to learning. Leveraging this theory allows for the promotion of online student actions/interactions and helps build a sense of community among the students. In the Global Policy Issues course the instructor used (LTCA) theory as a theoretical framework to support communication and learning as a means of sparking reflective thinking and communication regarding worldwide policy issues. A major goal of the technology implementation of Twitter was to encourage students to spend additional time on course tasks, enhance discourse amongst students, support improved learning, as well as provide students with a sense that they are part of a community of learners. By providing normative and strategic communicative actions the instructor helped govern students' use of Twitter. In constative discussions students engaged in discussions that emerged from teacher, expert, and student truth claims regarding global policy challenges. Further, through encouraging student dramaturgical expressions of truth and personal identity students expressed their subjective understandings of the discussed topics. These expressions were open for respectful public and peer critique.

\section{Merged Findings}

As noted, fast feedback was correlated with interactive learning, sense of community, communicate effectively, and helps understand readings. This supports hypothesis one together with the idea that students perceived the environment as freeflowing and interactive; thus, it was a space in which they engaged one another with the course content and sought common understandings. While the quantitative strand supported this, the qualitative strand confirms that students found that rapid feedback from peers and instructors provided a sense that their learning was interactive, required clear communication, and contributed to a sense of belonging to a class community.

Students also indicated that Twitter and the associated learning activities encouraged them to engage in different types of constative communication at different times. In some instances, the explicit or implicit normative communications among students helped build interdependence and challenged them to work more diligently. Several students also noted not only that they engaged in constative, collaborative communication that enabled intersubjective understandings to emerge, but also that this improved their learning. Constative communications are often free-flowing and always interactive, requiring rapid, argumentative discourse among participants. To be effective, it requires effective communication among all learners involved. It was also noted that students viewed the instructor's clarifying, directive strategic communications were beneficial to student learning and provided a strong reason to interact with Twitter. The dramaturgical actions that learners participated in were evidence of learning; however, such actions were mainly present in artifacts generated as a result of learning activities, rather than student utterances. Further, students self-identifying as shy viewed both 
constative and dramaturgical communication more positively, thus increasing their participation and communications geared towards learning.

The quantitative strand indicated a trend towards student perception of Twitter as helping increase understanding of course materials as supported by the interactive environment and affiliated, rapid feedback. In the qualitative strand, the general perception of the tool and its use to support learning indicate that it is a valuable addition to the classroom, fostering valuable constative communication among student participants and furthering learning. These findings support hypothesis two.

However, the qualitative strand also revealed an overall mixed view of the tool rather than strong consensus as to its worth, with females viewing it more positively than males and some females did note that, while they would not use Twitter in the future, they would use Facebook, a tool with similar communicative affordances. This is an indication that social media tools used for learning should be a design decision made based on student preferences rather than instructor inclination and would likely make the overall student experience shift from mixed to positive. It may also reduce the amount of time it takes students to acclimate to the associated learning activities, because the learning curve would be substantially reduced, possibly improving student perceptions of social media as a tool to support learning. These findings support our third hypothesis.

We believe that LTCA theory is a valuable framework for the 21 st century. It supports students by encouraging learning through those social media interactions that many students employ for interpersonal communication by engaging them in social discourses that allow shared meaning making and expression of personal identity. Overall, our findings indicate that social media tools such as Twitter may improve student academic experiences through increases in interactivity and discourses geared towards learning. We also note that students find that social media tools such as Twitter can strongly support the development of social presence and a sense of community among learners. This stems from participation in both argumentations towards shared understanding of content and the establishment of interdependence among learners resulting from freely-flowing communication among learners. Further, we note that providing students with a choice of tool may improve their perception of the use of social media to support learning.

Our study provides a window into the utility of blending learning-focused communicative actions with social media. Future research on the use of Twitter and other social media tools, employed in a more integrated fashion in a larger course, should help shed light on the usefulness of social media tools in education. Such research will stem from a design-based research model in which the curriculum will be constructed with social media as a central tool for enabling learning discourses rather than as supplement to other learning activities. We will further seek to integrate Learning and Teaching as Communicative Actions theory in a manner that allows us to match specific learning activities with their communicative action partners to identify a coherent instructional design model that increases access for other instructors should they choose to employ the framework.

\section{Acknowledgements}

The authors wish to acknowledge Gerald A. Knezek, Department of Learning Technologies, University of North Texas, for supporting this research. 


\section{References}

1. Anderson, D.M., \& Haddard, C.J. (2005). Gender, voice, and learning in online course environments. Journal of Asynchronous Learning Networks, 9 (1), 3-14.

2. Barab, S., \& Squire, K. (2004). Design-based research: Putting a stake in the ground. The Journal of the Learning Sciences, 13(1), 1-14.

3. Barrett, E., \& Lally, V. (1999). Gender differences in an online learning environment. Journal of Computer Assisted Learning, 15, 48-60.

4. Bernstein, R. J. (1983). Beyond Objectivism and Relativism: Science, Hermeneutics, and Praxis. Philadelphia: University of Pennsylvania Press.

5. Bianco, J.S. (2009). Social networking and cloud computing: Precarious affordances for the "prosumer". Women's Studies Quarterly, 37(1- 2), 303-311.

6. Bloom, B. (1968). Learning for mastery. Education and Curriculum. Available from ERIC, ED053419.

7. Boyd, D., Golder, S., \& Lotan, G. (2010). Tweet, tweet, retweet: Conversationsal aspects of retweeting on Twitter. Paper presented at HICSS-43.IEEE:Kauai, HI

8. Clark, R.E. (1994). Media will never influence learning. Educational Technology Research \& Development, 42(2), 21-29.

9. Creswell, J.S., \& Plano Clark, V.L. (2011). Designing and conducting mixed methods research. 2nd edition. Thousand Oaks, CA: Sage Publications Inc.

10. DeVellis, R. (1991). Scale development: Theories and application. Newbury Park, CA: Sage Publications.

11. Dunlap, J., \& Lowenthal, P.R. (2009a). Instructional uses of Twitter. In P. R. Lowenthal, D. Thomas, A.Thai, \& B. Yuhnke, B. (Eds.), The CU Online handbook. Teach differently: Create and collaborate (pp. 46-52). Raleigh, NC: Lulu Enterprises.

12. Dunlap, J.C., \& Lowenthal, P.R. (2009b). Tweeting the night away: Using Twitter to enhance social presence. Journal of Information Systems Education, 20(2), 129135.

13. Finlayson, J.G. (2005). Habermas: A very short introduction. Oxford, NY: Oxford University Press.

14. Gunawardena, C.N. (1995). Social presence theory and implications for interaction in and collaborative learning in computer conferences. International Journal of Educational Telecommunications 1(2/3), 147-166.

15. Gunawardena, C.N., \& Zittle, F. (1997). Social presence as a predictor of satisfaction within a computer-mediated conferencing environment. The American Journal of Distance Education, 11(3), 8-26.

16. Habermas, J. (1984). The theory of communicative action. Volume 1. Reason and the rationalization of society. (T. McCarthy). Boston, MA: Beacon Press. J. Habermas, 1981, Frankfurt am Main, Germany: Suhrkamp Verlag.

17. Habermas, J. (1998). On the pragmatics of communication. (M Cooke). Cambridge, MA: The MIT Press.

18. Herring, S.C. (2004). Computer-mediated discourse analysis: An approach to researching online behavior. In S. A. Barab, R. Kling \& J. H. Gray (Eds.), Designing virtual communities in the service of learning (pp. 338-376). Cambridge, UK: Cambridge University Press.Y: Oxford University Press. 
19. Honeycutt, C., \& Herring, S. (2009). Beyond microblogging: Conversation and collaboration via Twitter. Proceedings of the 42nd Hawaii International Conference on System Science.

20. Kim, J., Kwon, Y., \& Cho, D. (2011). Investigating factors that influence social presence and learning outcomes in distance education. Computers \& Education, 57, $1512-1520$.

21. Lave, J., \& Wenger, E. (1991). Situated learning. Legitimate peripheral participation. New York, NY: Cambridge University Press.

22. Lowenthal, P.R. (2009). Social presence. In P. Rogers, G. Berg, J. Boettcher, C. Howard, L. Justice, \& K. Schenk (Eds.), Encyclopedia of distance and online learning (2nd ed., pp. 1900-1906). Hershey, PA: IGI Global.

23. Neo, T.-K., \& Neo, M. (2004). Classroom innovation: Engaging students in interactive multimedia learning. The Campus-wide Information Systems, 21(3).

24. Ory, J.C., Bullock, C., \& Burnaska, K. (1997). Gender similarities in the use of and attitudes about ALN in a university setting. Journal of Asynchronous Learning Networks, 1(1), 1-16.

25. Palloff, R.M., \& Pratt, K. (2007). Building online learning communities. Effective strategies for the virtual classroom. San Francisco, CA: Jossey-Bass.

26. Parry, D. (2008). Twitter for academia. Retrieved from http://academhack.outsidethetext.com/home/2008/twitter-for-academia/.

27. Paulus, T.M., Payne, R., \& Jahns, L. (2009). Am I making sense here?: What blogging reveals about undergraduate student understanding. Journal of Interactive Online Learning, 8(1).

28. Quantcast. (2010). Twitter.com US demographics. Retrieved from http://www.quantcast.com/twitter.

29. Rankin. M. (2009). Some general comments on the Twitter experiment. Retrieved from http://bit.ly/IOLjs

30. Richardson, J.C., \& Swan, K. (2003). An examination of social presence in online courses in relation to students' perceived learning and satisfaction. Journal of Asynchronous Learning Networks, 7(1), 68-88.

31. Short, J., Williams, E., \& Christie, B. (1976). The social psychology of telecommunications. London: New York: John Wiley \& Sons. Inc.

32. Smith, J. (2010). December data on Facebook's US growth by age and gender: Beyond $100 \quad$ million. Retrieved from http://www.insidefacebook.com/2010/01/04/december-data-onfacebook\%E2\% $80 \% 99$ s-us-growth-by-age-and-gender-beyond-100-million/.

33. Somerville, M.M., \& Brar, N. (2010). From information to learning commons: campus planning highlights. New Library World, 111(5/6), 179 - 188.

34. Tu, C.-H. (2002). The relationship between social presence and online privacy. Internet and Higher Education, 5, 293-318.

35. Twitter Inc. (2011). Twitter is the best way to discover what's new in your world. Retrieved from http://twitter.com/about.

36. Wakefield, J.S., \& Warren, S.J. (2012). Learning and teaching as communicative actions: Social media as educational tool. In K. Seo (Ed), Using social media effectively in the classroom: blogs, wikis, Twitter, and more. Routledge/Taylor \& Francis. 
37. Warren, S.J. (2011). Learning and teaching as a communicative action. Retrieved from http://www.ltca.us/LTCA Theory.html.

38. Warren, S.J., Bohannon, R., \& Alajmi, M. (2010). Learning and teaching as communicative actions: An experimental course design. Paper presented at the American Educational Research Association Annual Meeting. Denver, CO.

39. Warren, S.J., \& Stein, R.A. (2008). Simulating teaching experience with role-play. In D. Gibson \& Y. Baek (Eds), Digital simulations for improving education. Learning through artificial teaching environments. Hershey, NY: Information Science Reference IGI Global.

40. Wenger, E. (2006). Communities of practice - A short introduction. Retrieved from $\mathrm{http}: / / \mathrm{www}$.ewenger.com/theory/communities_of_practice_intro.htm. 